\title{
WPŁYW REKOMENDACJI ZGROMADZENIA RADY EUROPY 1469 (2000) MATKI I DZIECI W WIĘZIENIU NA POLSKIE ROZWIAZZANIA PRAWA KARNEGO WYKONAWCZEGO
}

Obrona praw człowieka na gruncie międzynarodowym związana jest z ochroną wszystkich ludzi na świecie. Obrona ta obejmuje niemalże wszystkie sfery ich życia $^{1}$. Powszechna Deklaracja Praw Człowieka określa prawa człowieka, jako powszechne, niezbywalne i niepodzielne. Te cechy bez wątpienia mają ogromną wagę dla praw kobiet ${ }^{2}$. Proces kształtowania się międzynarodowych standardów wykonywania kary pozbawienia wolności rozpoczął się już w XIX w. ${ }^{3}$ Poszukiwanie metod, a także środków postępowania $\mathrm{z}$ kobietami, które odbywają karę pozbawienia wolności w zakładach karnych jest procesem długotrwałym. Zarówno teoretycy, jak również i praktycy spotykali się na Kongresach Penitencjarnych już od XIX wieku. Spotkania na międzynarodowych forach miały głównie na celu wypracowanie nowych, skutecznych metod postępowania ze skazanymi w zakładach karnych. Skutkiem tych spotkań, jak podkreśla G.B. Szczygieł ${ }^{4}$ jest wypracowanie zasad, które odnoszą się do problematyki wykonywania kary pozbawienia wolności. Znajdują się one w aktach, które posiadają różną moc wiążącą.

Potrzeba zmiany w podejściu do kobiet odbywających karę pozbawienia wolności została dostrzeżona, na gruncie prawa międzynarodowego. W granicach współpracy międzynarodowej o powszechnym charakterze (ONZ), a także regionalnym (Rada Europy) wypracowano liczne zasady, które odnoszą się do kobiet przebywających w warunkach izolacji penitencjarnej5.

Międzynarodowe standardy wykonywania kary pozbawienia wolności wyznaczają dwa dokumenty. Pierwszy z nich to Wzorcowe Reguły Minimum Postę-

1 T. Szymanowski, (w:) T. Szymanowski, J. Migdał, Prawo karne wykonawcze i polityka penitencjarna, Warszawa 2014, s. 49.

2 Ch. Bunch, S. Frost, Prawa kobiet w kontekście praw człowieka, (w:) A. Grzybek (red.), Prawa kobiet w dokumentach ONZ, Ośrodek Informacji Środowisk Kobiecych, Warszawa 1998, s. 15.

3 T. Szymanowski, Międzynarodowe standardy wykonywania kary pozbawienia wolności i ich respektowanie w polskim systemie penitencjarnym, PWP nr 50, Warszawa 2006, s. 23.

$4 \quad$ G. B. Szczygieł, Społeczna readaptacja skazanych w polskim systemie penitencjarnym, Białystok 2002, s. 35-36.

$5 \quad$ K. Sitnik, (w:) A. Kwieciński (red.), Postępowanie z wybranymi grupami skazanych w polskim systemie penitencjarnym, Warszawa 2013, s. 328. 
powania z Więźniami wypracowane w ramach systemu ONZ. Drugi dokument to Europejskie Reguły Więzienne, powstałe w Radzie Europy. Oba te dokumenty uwzględniają specyfikę sytuacji kobiet przebywających w warunkach izolacji penitencjarnej ${ }^{6}$. Jednakże należy zaznaczyć, że Reguły Minimum ONZ oraz Europejskie Reguły Więzienne zawierają jedynie podstawowe wskazania na temat wykonywania kary pozbawienia wolności w stosunku do kobiet. Rozpatrując zagadnienia kobiet odbywających karę pozbawienia wolności w polskich jednostkach penitencjarnych można sądzić, że jest to problem marginalny. Jednakże, biorąc pod uwagę istotę, odmienność, jak również specyfikę wykonywania kary pozbawienia wolności w stosunku do tej grupy skazanych, problem ten jawi się jako wyjątkowo ważny ${ }^{7}$.

Poszukiwania rozwiązań dotyczących odrębnego traktowania kobiet w zakładach karnych doprowadziło do ukształtowania się modelu postępowania z tą grupą skazanych. Wskazany stan rzeczy związany był z potrzebą odmiennego traktowania kobiet ze względu na ich biologiczne, a także psychiczne uwarunkowanie płci. W związku z powyższym, w celu ukazania międzynarodowych standardów dotyczących traktowania kobiet przebywających w warunkach izolacji penitencjarnej, należy wskazać następujące dokumenty:

1. Rekomendacja 1469 (2000) Matki i dzieci w więzieniu

2. Rezolucja Parlamentu Europejskiego z dnia 13 marca 2008 r. w sprawie szczególnej sytuacji kobiet w więzieniach oraz wpływu pobytu rodziców W więzieniu na życie społeczne i rodzinne $\left(2007 / 2116(\text { INI) })^{9}\right.$;

3. Rezolucja 1663 (2009) Kobiety w więzieniu ${ }^{10}$.

Zdaniem I. Dybalskiej ${ }^{11}$, na szczególną uwagę zasługuje fakt, że z chwilą wejścia w życie obecnie obowiązującego prawa karnego wykonawczego, normą prawną objęte zostały wszystkie obszary postępowania w stosunku do kobiet pozbawionych wolności. To właśnie te kobiety stanowiły przedmiot rekomendacji w Projekcie Sprawozdania Komisji Praw Kobiet i Równouprawnienia Parlamentu Europejskiego w sprawie szczegółowej sytuacji kobiet w więzieniu oraz wpływu pobytu rodziców w więzieniu na życie społeczne i rodzinne.

W wielu państwach członkowskich Rady Europy (pkt 2) wzrasta liczba kobiet, w stosunku do których sąd orzeka karę pozbawienia wolności bądź tymcza-

$6 \quad$ K. Więckiewicz, (w:) A. Rzepiński, I. Rzepińska, M. Niebaczna, P. Wiktorska (red.), Pozbawienie wolności - funkcje i koszty. Księga jubileuszowa Profesora Teodora Szymanowskiego, Warszawa 2013, s. 666. $\mathrm{H}$. Machel, Sens i bezsens resocjalizacji penitencjarnej - casus polski. Studium penitencjarno-pedagogiczne, Kraków 2006, s. 217.

8 Rekomendacja 1469 (2000) Matki i dzieci w więzieniu, „Przegląd Więziennictwa Polskiego” 2011, nr 72-73, s. 169 in.

9 Rezolucja Parlamentu Europejskiego z dnia 13 marca 2008 r. w sprawie szczególnej sytuacji kobiet w więzieniach oraz wpływu pobytu rodziców w więzieniu na życie społeczne i rodzinne (2007/2116(INI)), (Dz.U. UE C 2009 66E 49).

10 Rezolucja 1663 (2009) Kobiety w więzieniu, „Przegląd Więziennictwa Polskiego” 2011, nr 72-73, s. 153 i n.

11 I. Dybalska, (w:) I. Dybalska (red.), Kobieta w więzieniu - polski system penitencjarny wobec kobiet w latach 1998-2008, Warszawa 2009, s. 28. 
sowego aresztowania. Znaczna część kobiet, która jest kierowana do więzienia są to kobiety, które dopuściły się drobnego przestępstwa i w związku z powyższym nie stanowią zagrożenia dla społeczeństwa. Brak jest danych dotyczących liczby niemowląt oraz małych dzieci odseparowanych od swoich matek, z uwagi na ich przebywanie w więzieniu (punkt 3$)^{12}$. Przytaczając szacunki Ligi Howarda, Zgromadzenie podkreśla, że w krajach europejskich liczba niemowląt oraz małych dzieci, które są oddzielone od matek w wyniku ich przebywania w więzieniu dotyka 10 tys. niemowląt oraz dzieci poniżej 2. roku życia. Jest to zjawisko bardzo niepokojące, szczególnie ze względu na prawidłowy rozwój dziecka. Z licznych badań wynika, że rozdzielenie dziecka od matki na tak wczesnym etapie jego życia ma bardzo negatywne skutki w procesie jego rozwoju. Niezaspokojenie podstawowych potrzeb niemowlęcia oraz małego dziecka, w postaci bliskiego kontaktu i zapewnienia bezpieczeństwa, zaburza oraz hamuje wszelkie formy rozwoju dziecka, w tym rozwój poznawczy, społeczny, a także emocjonalny. Podkreślić należy, że zaburzenia powstałe w tak wczesnym okresie życia dziecka, znacząco rzutują na późniejszy jego rozwój. Często też zaburzenia powstałe we wczesnym okresie życia mają negatywny wpływ na funkcjonowanie psychospołeczne w dorosłym życiu ${ }^{13}$. Eksperci podkreślają także, że rozdzielenie matki z dzieckiem na tak wczesnym etapie stanowi źródło długotrwałych trudności związanych głównie z problemem zaburzenia zdolności przywiązywania się do innych ludzi, nieprzystosowania społecznego, a także zaburzenia osobowości. Z drugiej strony dodają, że w warunkach więziennych, rozwój niemowląt oraz małych dzieci także ulega zaburzeniu, z uwagi na ograniczony dostęp do szerokiego wachlarza bodźców (punkt 4) ${ }^{14}$. Rozerwanie więzi rodzinnych może prowadzić do poważanego zakłócenia życia rodzinnego. Rozdzielenie dziecka od matki na wczesnym etapie jego życia powoduje negatywne skutki. W zakresie więzi rodzinnych oraz stosunków społecznych zaleca się częstsze stosowanie kar zastępczych zamiast kar więzienia, zwłaszcza w przypadku matek, ponieważ przewidziana kara oraz zagrożenie bezpieczeństwa publicznego są niskie ${ }^{15}$. Konwencja o prawach dziecka zakazuje zrywania więzi łączących dziecko z osobami sprawującymi nad nim pieczę. Już w preambule konwencji uznaje, że dziecko dla pełnego i harmonijnego rozwoju swojej osobowości powinno wychowywać się w środowisku rodzinnym, w atmosferze szczęścia, miłości i zrozumienia ${ }^{16}$. Przerwanie związków uczuciowych w dzieciństwie grozi psychicznym kalectwem utrudniającym lub uniemożliwiającym rozwój zdolności kochania ${ }^{17}$.

\footnotetext{
12 Rekomendacja 1469 (2000) Matki i dzieci w więzieniu, „Przegląd Więziennictwa Polskiego” 2011, nr 72-73, s. 167

13 A. Szymanowska, Rekomendacja 1469 (2000) Matki i dzieci w więzieniu. Komentarz, „Przegląd Więziennictwa Polskiego" 2011, nr 72-73, s. 169.

14 Rekomendacja..., op. cit., s. 167.

$15 \quad$ K. Sitnik..., op. cit., s. 332.

16 O. Sitarz, Ochrona praw dziecka w polskim prawie karnym na tle postanowień konwencji o prawach dziecka, Katowice 2004, s. 180.

17 Ibidem, s. 191.
} 
Zgromadzenie, dostrzegając negatywne skutki odłączenia dziecka od matki zaleca, żeby Komitet Ministrów zachęcił państwa członkowskie do unikania stosowania kar pozbawienia wolności w stosunku do kobiet w ciąży oraz matek posiadających małe dzieci. W celu zmniejszenia liczby kobiet w ciąży oraz matek posiadających małe dzieci w zakładach karnych trzeba opracować odpowiednie wytyczne, skierowane do sądów. Zgodnie z tymi wytycznymi sądy mogłyby rozważać orzeczenie kary pozbawienia wolności w stosunku do tej grupy osób (punkt 5.7) ${ }^{18}$. Kara pozbawienia wolności w stosunku do tej kategorii osób powinna zostać zastosowana tylko w ostateczności i tylko wobec kobiet, które dopuściły się poważnych przestępstw, szczególnie z użyciem przemocy oraz pod warunkiem, że stanowią one ciągłe zagrożenie dla społeczeństwa ${ }^{19}$.

Ponadto, należy zachęcić państwa członkowskie do tworzenia zamkniętych oraz półotwartych placówek (punkt 5.4), których celem będzie zagwarantowanie pomocy społecznej dla niewielkiej liczby matek, wymagających tego nadzoru. Priorytetem funkcjonowania takich placówek ma być przede wszystkim dobro dziecka. Opieka nad dzieckiem powinna być sprawowana w odpowiednim dla nich środowisku. Trzeba pamiętać, że należy dołożyć wszelkich starań, żeby opieka nad dzieckiem była sprawowana przy zachowaniu bezpieczeństwa publicznego ${ }^{20}$. W celu zniwelowania negatywnych skutków, jakie pozbawienie wolności matki wywiera na dziecko, należy zachęcić państwa członkowskie do opracowania na bazie Konwencji ONZ o Prawach Dziecka oraz Europejskiej Konwencji Praw Człowieka (punkt 5.2) programów edukacyjnych obejmujących swoim zakresem problemy matek oraz małych dzieci. Programy edukacyjne powinny być przeznaczone dla specjalistów, którzy pracują w obszarze wymiaru sprawiedliwości ${ }^{21}$. Tym samym warto zadbać o zapewnienie odpowiedniego przeszkolenia dla personelu służby więziennej w zakresie opieki nad dziećmi (punkt 5.6).

Ponadto, należy zapewnić ojcu możliwość lepszych warunków do odwiedzania dzieci. Bardzo istotne jest, żeby dzieci mogły spędzać czas zarówno z matką, jak również i z ojcem (punkt 5.5).

Zgodnie z art. $87 \S 4$ kodeksu karnego wykonawczego w polskim systemie penitencjarnym organizuje są domy dla matki i dziecka, które mieszczą się przy wskazanych zakładach karnych ${ }^{22}$. Na podstawie art. $87 \S 4$ kodeksu karnego wykonawczego ${ }^{23}$ zostało wydane rozporządzenie Ministra Sprawiedliwości w sprawie trybu przyjmowania dzieci matek pozbawionych wolności do domów dla matki i dziecka. Zgodnie z rozporządzeniem matka pozbawiona wolności sprawuje stałą i bezpośrednią opiekę nad dzieckiem w domu dziecka dla matki i dziecka przy zakła-

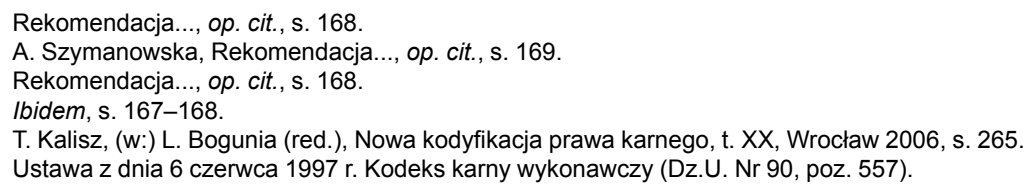


dzie karnym, który zwany jest „,domem” w Zakładzie Karnym Nr 1 w Grudziądzu oraz Zakładzie Karnym w Krzywańcu ${ }^{24}$. Domy te mają do dyspozycji 61 miejsc ${ }^{25}$.

Dom dla Matki i Dziecka, mieszczący się przy Zakładzie Karnym Nr 1 w Grudziądzu jest placówką opiekuńczo-wychowawczą. W Grudziądzu znajduje się jedyny w Polsce więzienny oddział ginekologiczno-położniczy, w którym skazane kobiety rodzą dzieci. Macierzyństwo jest stanem, który zmienia każdą kobietę, również tę, która przebywa w warunkach izolacji penitencjarnej. Kobiety w ciąży, które odbywają karę pozbawienia wolności od momentu przybycia do zakładu karnego objęte zostają wywiadami zarówno bezpośrednimi, jak również i pośrednimi. W związku z tym kierownik Domu Matki i Dziecka ma kompletne rozeznanie w ich sytuacji rodzinnej oraz w jaki sposób do tej pory spełniały się w roli matki ${ }^{26}$.

Wszystkie pomieszczenia domu powinny być zbliżone wyposażeniem do warunków domowych. Dom ten powinien składać się z pomieszczeń, takich jak:

1) pokoje sypialne dla matek $z$ dziećmi;

2) sale do zajęć pielęgnacyjnych oraz wychowawczych;

3) pomieszczenia do udzielania świadczeń zdrowotnych;

4) pomieszczenie do przygotowania posiłków;

5) pomieszczenie sanitarne oraz gospodarcze;

6) pokoje dla personelu;

7) pomieszczenie izby chorych.

Zasadą stało się, że funkcjonariusze Służby Więziennej, którzy mają bezpośredni kontakt z dziećmi, podczas pełnienia służby nie używają służbowego umundurowania ${ }^{27}$.

Skazane kobiety mają możliwość rozwiązania swoich problemów na etapie trwania ciąży. Kobiety, które są uzależnione od alkoholu mają możliwość odbycia leczenia odwykowego w specjalnym oddziale terapeutycznym. Na potrzeby skazanych uzależnionych od narkotyków sprowadza się terapeutów spoza zakładu karnego, z którymi skazane pracują indywidualnie. Na etapie trwania ciąży rozpoczyna się indywidualna praca z kobietami, które są ofiarami przemocy domowej. Uzyskują one pakiet informacji, w momencie opuszczania zakładu karnego o instytucjach, w których mogą szukać pomocy. W stosunku do skazanych kobiet w ciąży realizowany jest również projekt „,Dar rodzenia”. Program ten kierowany jest do kobiet w ciąży. Stanowi od podłoże do pełnienia roli matki. W programie tym znajdują się

24 Rozporządzenia Ministra Sprawiedliwości z dnia 17 września 2003 r. w sprawie trybu przyjmowania matek pozbawionych wolności do domów dla matki i dziecka przy wskazanych zakładach karnych oraz szczegółowych zasad organizowania i działania tych placówek (Dz.U. z 2003 r. Nr 175, poz. 1709).

25 I. Dybalska, op. cit., s. 43.

26 H. Reczek, op. cit., s. 231.

27 Rozporządzenia Ministra Sprawiedliwości z dnia 17 września 2003 r. w sprawie trybu przyjmowania matek pozbawionych wolności do domów dla matki i dziecka przy wskazanych zakładach karnych oraz szczegółowych zasad organizowania i działania tych placówek (Dz.U. z 2003 r. Nr 175, poz. 1709). 
zarówno informacje medyczne i psychologiczne, przygotowujące do porodu oraz zagadnienia prawne i pedagogiczne ${ }^{28}$.

Z badań przeprowadzonych w latach 1987-1995 w Domu Matki i Dziecka w Krzywańcu wynika, że spośród 58 matek:

1) 33 wychowuje swoje dzieci w domach rodzinnych i nie ma żadnych uwag odnośnie sprawowania przez nich tej roli;

2) 6 dzieci zostało przekazanych do adopcji;

3) 5 dzieci przebywa w rodzinach zastępczych, ponieważ ich matka nadal odbywa karę pozbawienia wolności;

4) w jednym przypadku nastąpił zgon dziecka ${ }^{29}$.

Nikt nie twierdzi, że pobyt dziecka wraz z matką w więzieniu jest najlepszym rozwiązaniem. Jednakże należy pamiętać, że do tej pory nie wymyślono innego sposobu, który uchroniłby dziecko przed chorobą sierocą ${ }^{30}$. Warto $\mathrm{w}$ tym momencie przytoczyć wyniki badań, przeprowadzonych przez R. Spitza. Badania te zostały dokonane na grupie dzieci, które przebywały w sierocińcu, natomiast zostały urodzone podczas pobytu matki w zakładzie karnym. Przez pierwsze 6 miesięcy dzieci te przebywały wraz ze swoimi matkami, następnie po tym okresie zostały przeniesione do sierocińca. Pierwszy miesiąc po oddzieleniu dziecka od matki minął w smutku i płaczu. Po dwóch miesiącach rozłąki z matką dzieci te płakały niemal bez przerwy, doszły także problemy utraty wagi oraz zahamowanie rozwoju. W dziewiątym miesiącu dzieci odseparowane od matki cierpiały na bezsenność i nie czyniły prób nawiązania z kimkolwiek kontaktu. W dwunastym miesiącu dzieci były całkowicie bierne, całymi dniami trwały w bezruchu. W wieku 2 lat nie potrafiły siedzieć, stać, mówić, natomiast ich poziom inteligencji wynosił zaledwie $45 \%$ poziomu właściwego dla dziecka w tym wieku. Pomimo faktu, że dzieci te miały zapewnioną doskonałą opiekę medyczną ze strony personelu, a także właściwe odżywianie, to brakowało im najważniejszego - stałego i bezpośredniego kontaktu z matką ${ }^{31}$. Niekwestionowany jest bowiem fakt, że obecność matki jest niezbędna do prawidłowego rozwoju emocjonalnego dziecka, a także jego prawidłowych odruchów. Dzieci przebywające w Domu Matki i Dziecka w Krzywańcu mają zapewnioną codzienną opiekę matki oraz wykwalifikowanego personelu więziennego (pielęgniarki, lekarza) ${ }^{32}$. Znaczna liczba kobiet odbywających karę pozbawienia wolności ma duży deficyt w zakresie macierzyństwa ${ }^{33}$. Bardzo dużym problemem wśród skazanych kobiet jest trudność w wywiązywaniu się z roli matki. Jest to bardzo czasochłonne działanie, ponieważ

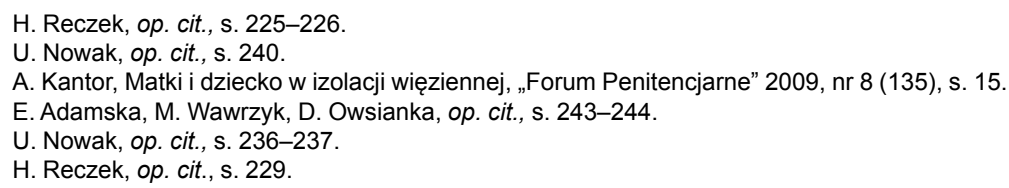


nikt im wcześniej nie pokazał jak być matką ${ }^{34}$. Należy zaznaczyć, że bardzo dużo zależy od samej matki. Niezbędna jest chęć skazanej matki do podjęcia współpracy z innymi ludźmi, świadomość jej zachowania, a także wpływ na rozwój psychofizyczny dziecka. Głównym zadaniem oddziaływania psychologicznego w stosunku do skazanych matek jest wzbudzenie w nich chęci oraz potrzeby otoczenia dziecka miłością, szacunkiem, opieką. Ponadto psycholodzy stosują wobec tej kategorii skazanych oddziaływania, dzięki którym matki mają zastymulować całkowity rozwój zarówno fizyczny, jak również i psychiczny swego dziecka ${ }^{35}$.

W orzecznictwie podkreśla się także możliwość odroczenia wykonywania kary w stosunku do kobiety ciężarnej, jak też osoby skazanej, która samotnie sprawuje opiekę nad dzieckiem do trzeciego roku życia ${ }^{36}$. O takiej możliwości stanowi art. $151 \S 1$ zdanie 2 kodeksu karnego wykonawczego. Z artykułu tego wynika, że w stosunku do skazanej kobiety ciężarnej oraz osoby skazanej samotnie sprawującej opiekę nad dzieckiem sąd może odroczyć wykonanie kary na okres do 3 lat po urodzeniu dziecka ${ }^{37}$. Jest to według T. Szymanowskiego racjonalne rozwiązanie podyktowane humanizmem w postępowaniu ze skazanymi rodzicami, a także, co ważne, zabezpieczeniem prawidłowego rozwoju dzieci ${ }^{38}$.

Opierając się na analizie przepisów prawa w Polsce, które dotyczy wykonywania kary pozbawienia wolności w stosunku do kobiet w ciąży oraz matek posiadających małe dzieci, można stwierdzić, że Polska respektuje wszystkie zalecenia Zgromadzenia unormowane w Rezolucji 1469 (2000) dotyczącej Matek i dzieci w więzieniu.

J. Nielubowicz, M. Niemiec, op. cit., s. 158.

E. Adamska, M. Wawrzyk, D. Owsianka, op. cit., s. 253.

A. Kwieciński, Skazani - rodzice. Sytuacja prawna osadzonych sprawujących opiekę nad dziećmi (w:) T. Kalisza (red.), Nowa kodyfikacja prawa karnego, t. XXVIII, s. 193.

Ustawa z dnia 6 czerwca 1997 r. Kodeks karny wykonawczy (Dz.U. Nr 90, poz. 557).

T. Szymanowski, Z. Świda, Kodeks karny wykonawczy. Komentarz. Ustawy dodatkowe. Akty prawne, Warszawa 1998, s. 348. 


\section{INFLUENCE OF THE RECOMMENDATION OF ATTRACTING EUROPEAN COUNCIL 1469 (2000) MOTHERS AND CHILDREN IN PRISON FOR POLISH TERMINATIONS OF THE IMPLEMENTATION CRIMINAL LAW}

The article shows the specificity of situations involving women serving a penalty of imprisonment. In recent years it has been noticed that the number of women committing offences has reached new heights. A close examination of this problem is essential since punishing woman, particularly mothers, with custodial sentences in a penitentiary, often leads to a sequence of adverse effects. In the interests of minimising those effects, one should consider avoiding the application of such custodial sentences where they involve pregnant women and mothers of small children. The article suggests legal solutions toward this end that are available both in international as well as domestic law.

Keywords: woman, child, penitentiary, penalty of imprisonment 